\title{
Digital Economy Development as a Prerequisite for Innovation Activities
}

\author{
Sviridova T.G.* \\ Department of Economic Security and Financial Monitoring \\ Voronezh State University of Engineering Technologies \\ Voronezh, Russian Federation \\ e-mail: tanechka_sviridova@mail.ru
}

Sokolinskaya Y.M.

Department of Economic Security and Financial Monitoring Voronezh State University of Engineering Technologies

Voronezh, Russian Federation

e-mail: misterias@mail.ru

\begin{abstract}
The subject of the research is the study of prerequisites for the formation of a new technological basis for Russian economy. Russian economy faces the task of activating innovative factors, ensuring high dynamics of development and increasing the competitiveness of various business entities. To solve this problem at the macro level, it is necessary to create a system based on the principles of digital economy. These principles are being transformed into a system of economic relations based on the transition to highly automated production systems and digital information and communication technologies. This transition involves not only global prospects, but also dangers and risks. Several strategies for digital restructuring of the country's economy based on gradual and long-term development are proposed.
\end{abstract}

Keywords - Digital economy, innovative development, digitalization of production, development strategies, information technologies

\section{INTRODUCTION}

Since electronic technologies and services become the key factors of economic activity in the new economy, as well as large, multi-industry data presented in digital form, the processing and analysis of which makes it possible to significantly increase efficiency and quality in the production and consumption of goods, works and services, as well as in management procedures, the competitive advantage is enjoyed by those States whose economy is based on the most advanced electronic technologies and services, including "big data" analysis technologies and predictive technologies.

Nowadays the states the economy of which is based on the most advanced electronic technologies and services, including "big data" analysis technologies and predictive technologies enjoy the competitive advantage. We can explain this fact by the increased role of electronic technologies and services the in economic processes as well as large, multi-industry digital

\author{
Chekudaev K.V. \\ Department of Economic Security and Financial Monitoring \\ автора \\ Voronezh State University of Engineering Technologies \\ Voronezh, Russian Federation \\ e-mail: chkv1985@mail.ru
}

\author{
Kolesnichenko E.A. \\ Department of Personnel Management \\ Tambov State University \\ Tambov, Russian Federation \\ e-mail ekolesnichenko@live.ru
}

data. The processing and analysis of this data allow significant increase in efficiency and quality of management, production and consumption of goods, works and services.

Currently, the Russian economy faces the task of activating innovative factors, ensuring high dynamics of development, and improving the competitiveness of various business entities. To solve this problem at the macro level, it is necessary to create a system based on the principles of the digital economy [1]. These principles are being transformed into a system of economic relations based on the transition to highly automated production systems and digital information and communication technologies. Thus, the key factor for the success of business entities in the conditions of a turbulent external environment is a focus on the creation and use of various types of innovations, digitalization of production.

The modern market of high-tech products is characterized by the constant formation of new segments, the emergence of new forms of competition. For example, the results of research conducted by the Global Center for Digital Business Transformation have shown that in the coming years, digital revolution can displace up to $40 \%$ of subjects from the market of high-tech products, if they do not undergo digital transformation [1]. This conclusion applies not only to market outsiders, but also to those structures that currently occupy a leading position in the market. Digitalization is not limited to a drastic increase in the level of automation of production systems. It also involves transferring the management of various business processes to the electronic space. This means the formation of qualitatively new models for managing such categories as R \& d, demand, supply, document flow, etc. In addition, the digitalization of economy gives rise to new business models, such as systems that ensure the production of qualitatively new knowledge-intensive products. One of these models is innovation-oriented cluster structures [2]. These entities are based on business processes for creating and using innovations [3]. Firstly, technological innovations that cover 
the classes of product (new products) and process (new technologies) innovations. Secondly, they cover organizational and managerial, involving the use of new methods of organization and management. Thirdly, they cover resourcebased processes that provide realizable business processes with resources with new properties and quality indicators. This list can include marketing, financial, economic, and other types of innovations. The types of innovations listed above form an innovative subsystem of the cluster structure, which should be managed in a digital format. In this case, innovation-oriented cluster structures should have a high level of intellectual potential of the person. The realization of this potential makes it possible, first, to integrate innovative elements created or acquired under license agreements into the activities of the cluster structure with minimal communication costs, and second, to ensure the transition to digital technologies. This contributes to the fact that the key sources of development of the cluster structure, along with traditional resources (financial and material), are such elements as information and human capital.

The cybernetic approach to building an innovationoriented cluster structure management system leads to the fact that the system becomes multi-level, covering:

- level of management of production resources (material and intellectual);

- $\quad$ level of process control (process innovations);

- $\quad$ level of product management (product innovations);

- the management level of the cluster structure's relationship with consumers.

For the purpose of managing an innovation-oriented cluster structure, various classes of information systems are used [4]. First of all, MES-systems (Manufacturing Execution System) are used for managing production processes; MRPsystems (Material Requirements Planning), covering the processes of planning the need for materials; ERP-systems (Enterprise Resource Planning), providing integration of processes for managing production, human resources, Finance and assets; PDM-systems (Product Data Management) that allow managing all information about products; CRM-systems (Customer Relationship Management) that regulate the processes of customer relationship management.

The use of such systems increases the efficiency and effectiveness of functioning not only of a highly automated system, but also of the activity of an innovation-oriented cluster structure in General. For example, in the information systems we mentioned earlier, the unity of the information space means that data from software applications of a highly automated production system becomes available in real time to all divisions of the cluster structure [5].

In addition, a highly automated system should have a high level of flexibility when changing factors of production, including changes in the field of information technology. This property implies the possibility of integrating additional applications into the system and using new information technologies. The implementation of the flexibility property in relation to changes in informational communication factors ensures the continuity of the processes of modernization of the production system by changing the quality of information resources.

The legal basis of the digital economy development Program in the Russian Federation is the Constitution of the Russian Federation, Federal law No. 172-FL of June 28, 2014 "On strategic planning in the Russian Federation", as well as the provisions of Federal laws, acts of the President of the Russian Federation and the Government of the Russian Federation, and other regulatory legal acts regulating the sphere of information and communication technologies in relation to the formation of a new technological basis for the domestic economy.

Currently, three official strategies for the development of the Russian economy in 2017-2035 are being discussed. They were presented to the public during the St. Petersburg international economic forum on June 1-3, 2017:

1. Humanitarian breakthrough instead of mobilization (A. Kudrin, center for strategic development).

2. Growth strategy (B. Titov, the Stolypin club, the Institute of Economics of growth named after P. A. Stolypin).

3. Strategy of the Russian Government (M. Oreshkin et al., Ministry of Economic development of the Russian Federation).

Their main directions and characteristics are presented in table I.

TABLE I. STRATEGY OF DEVELOPMENT OF THE RUSSIAN ECONOMY IN THE YEARS FOR 2035

\begin{tabular}{|c|c|c|c|c|c|c|}
\hline \multirow{2}{*}{$\begin{array}{c}\text { Developm } \\
\text { ent } \\
\text { strategy } \\
\text { (Institute, } \\
\text { organizati } \\
\text { on, } \\
\text { specialist) }\end{array}$} & \multirow[b]{2}{*}{$\begin{array}{c}\text { Main } \\
\text { direction }\end{array}$} & \multirow[b]{2}{*}{$\begin{array}{c}\text { Stages of } \\
\text { strategy } \\
\text { implement } \\
\text { ation }\end{array}$} & \multicolumn{4}{|c|}{ GDP growth, \% } \\
\hline & & & 2017 & 2018 & 2027 & 2035 \\
\hline $\begin{array}{l}\text { Humanitari } \\
\text { an } \\
\text { breakthrou } \\
\text { gh instead } \\
\text { of } \\
\text { mobilizatio } \\
\text { n (center } \\
\text { for } \\
\text { strategic } \\
\text { developme } \\
\text { nt, A. } \\
\text { Kudrin) }\end{array}$ & $\begin{array}{l}\text { financin } \\
\mathrm{g} \text { the } \\
\text { implementa } \\
\text { tion of the } \\
\text { 4th } \\
\text { industrial } \\
\text { revolution; } \\
\text { providin } \\
\mathrm{g} \text { the } \\
\text { economy } \\
\text { with a high- } \\
\text { quality } \\
\text { workforce } \\
\text { through } \\
\text { investment } \\
\text { in medicine } \\
\text { and } \\
\text { education; } \\
\text { digitaliz } \\
\text { ation of the } \\
\text { public } \\
\text { sector, a } \\
\text { combinatio } \\
\mathrm{n} \text { of project } \\
\text { and process } \\
\text { managemen }\end{array}$ & $\begin{array}{l}\quad \text { Stage 1: } \\
\text { economic } \\
\text { growth due } \\
\text { to the } \\
\text { Russian } \\
\text { technologic } \\
\text { al } \\
\text { revolution } \\
\text { (a } \\
\text { prototype } \\
\text { of the } \\
\text { concept of } \\
\text { industry } \\
\text { 4.0), } \\
\text { national } \\
\text { technology } \\
\text { initiative; } \\
\text { developme } \\
\text { nt of the } \\
\text { digital } \\
\text { economy, } \\
\text { creation of } \\
\text { standards } \\
\text { for the } \\
\text { digital } \\
\text { economy; }\end{array}$ & 1,6 & 3,2 & 4,2 & 3,7 \\
\hline
\end{tabular}




\begin{tabular}{|c|c|c|c|c|c|c|}
\hline & $\begin{array}{l}\text { t methods; } \\
\text { increasin } \\
\mathrm{g} \text { the } \\
\text { retirement } \\
\text { age } \quad 63 \\
\text { years for } \\
\text { women, } 68 \\
\text { years for } \\
\text { men). }\end{array}$ & $\begin{array}{l}\text { doubling } \\
\text { the non- } \\
\text { resource } \\
\text { sector. } \\
\quad \text { Stage } 2 . \\
\text { Growth of } \\
\text { investments } \\
\text { achieved in } \\
\text { stage } 1 \text { in } \\
\text { education, } \\
\text { medicine, } \\
\text { and } \\
\text { infrastructu } \\
\text { re. }\end{array}$ & & & & \\
\hline 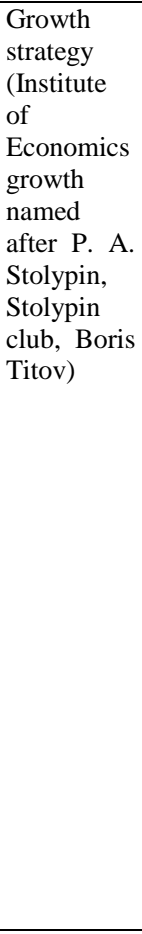 & $\begin{array}{l}\text { promotio } \\
\mathrm{n} \quad \text { of } \\
\text { developme } \\
\mathrm{nt} \\
\text { institutions } \\
\text { (industrial } \\
\text { developme } \\
\text { nt Fund, } \\
\text { Russian } \\
\text { venture } \\
\text { company, } \\
\text { Agency for } \\
\text { strategic } \\
\text { initiatives, } \\
\text { etc.); } \\
\text { creation } \\
\text { of the } \\
\text { Institute of } \\
\text { project } \\
\text { Finance; } \\
\quad \text { creating } \\
\text { a favorable } \\
\text { tax climate; } \\
\text { develop } \\
\text { ment of } \\
\text { small and } \\
\text { medium- } \\
\text { sized } \\
\text { businesses. }\end{array}$ & \begin{tabular}{l}
\multicolumn{1}{c}{ Stage 1.} \\
Restorative \\
- \\
developme \\
nt of the \\
domestic \\
market. \\
$\quad$ Stage 2. \\
Investment \\
growth - \\
creating \\
conditions \\
for \\
attracting \\
investment. \\
$\quad$ Stage 3 . \\
Sustainable \\
growth- \\
formation \\
of \\
innovative \\
sectors of \\
the \\
economy, \\
access to \\
foreign \\
markets.
\end{tabular} & 1,5 & 2,8 & 3,5 & 4,5 \\
\hline $\begin{array}{l}\text { Strategy of } \\
\text { the Russian } \\
\text { Governme } \\
\text { nt } \\
\text { (Ministry } \\
\text { of } \\
\text { economic } \\
\text { developme } \\
\text { nt of the } \\
\text { Russian } \\
\text { Federation, } \\
\text { M. } \\
\text { Oreshkin) } \\
\text { Catch-up } \\
\text { strategy) }\end{array}$ & $\begin{array}{l}\text { Areas of } \\
\text { developme } \\
\text { nt: } \\
\text { stabilizatio } \\
\mathrm{n} \text { of the } \\
\text { economy, } \\
\text { formation } \\
\text { of domestic } \\
\text { consumer } \\
\text { demand; } \\
\text { attracting } \\
\text { investment; } \\
\text { optimizatio } \\
\mathrm{n} \text { of the tax } \\
\text { system; } \\
\text { developme } \\
\text { nt of } \\
\text { innovations } \\
; \\
\text { digitalizatio } \\
\mathrm{n} \text { of the } \\
\text { economy; } \\
\text { improving } \\
\text { the } \\
\text { effectivenes } \\
\mathrm{s} \quad \text { of } \\
\text { government } \\
\text { programs; } \\
\text { developme }\end{array}$ & & 1,8 & & 3,5 & \\
\hline
\end{tabular}

\begin{tabular}{|c|c|c|c|c|}
\hline & $\begin{array}{l}\text { nt of small } \\
\text { and } \\
\text { medium- } \\
\text { sized } \\
\text { businesses, } \\
\text { etc. }\end{array}$ & & & \\
\hline $\begin{array}{l}\text { World } \\
\text { average } \\
\text { indicators } \\
\text { (President } \\
\text { of the } \\
\text { Russian } \\
\text { Federation) }\end{array}$ & & \multicolumn{3}{|c|}{$3-3,5 \%$ per year } \\
\hline $\begin{array}{l}\text { Economic } \\
\text { parity } \\
\text { strategy } \\
\text { (Gref) }\end{array}$ & & \multicolumn{3}{|c|}{$6-8 \%$ per year } \\
\hline $\begin{array}{l}\text { Internation } \\
\text { al } \\
\text { Monetary } \\
\text { Fund } \\
\text { (IMF) } \\
\text { (forecast in } \\
\text { Russia) }\end{array}$ & & 1,4 & $\begin{array}{ll}1,9 \% & \text { for } \\
2020 \text { г. } & \end{array}$ & \\
\hline $\begin{array}{l}\text { World } \\
\text { economy }\end{array}$ & & 2,0 & $3-3,5 \%$ & \\
\hline $\begin{array}{l}\text { China's } \\
\text { economy } \\
\text { (13th five- } \\
\text { year plan, } \\
\text { "Made in } \\
\text { China } \\
2025 ", \\
\text { "Internet } \\
\text { plus" } \\
\text { programs) } \\
2015\end{array}$ & & \multicolumn{3}{|c|}{$\begin{array}{c}2015-2020-\text { annual growth } \\
6-6,3 \%\end{array}$} \\
\hline
\end{tabular}

The impact of mobile economy is not only evident in companies directly doing business in the mobile industry. As of 2019, the total indirect contribution of the mobile economy was approximately 2,140 billion rubles. About 1.1 million people are employed in the mobile economy, $55 \%$ of them - in large companies. Over the next 5 years, about 430,000 new jobs will be created in the mobile economy, for example, in mobile Commerce and related segments. A distinctive feature of Russia from other markets is the high level of indirect contribution (process optimization) of mobile technologies to the national economy and the high growth rate of this contribution. According to preliminary estimates, the overall growth may reach $35 \%$ by 2021 (in the US and China, this figure is estimated at $25 \%$ and $31 \%$, respectively.

\section{METHODS AND MATERIALS}

Digitalization will affect all major markets that currently exist. In addition, as a result of the transformation, new markets will appear. Most markets will be networked. The new markets will be focused on a person as a final consumer, and the distance between a producer and a consumer will be minimal [6].

Within the framework of innovative technologies, Russia will focus on those markets where it is possible to create industries of a new technological order that are significant in terms of ensuring national security and a high standard of living for 
citizens. The most promising areas of development are presented in table II.

TABLE II. MAIN DIRECTIONS OF DIGITAL ECONOMY DEVELOPMENT

\begin{tabular}{|c|c|c|}
\hline $\begin{array}{l}\text { Development } \\
\text { direction }\end{array}$ & Subject area & Development perspective \\
\hline AeroNet & $\begin{array}{l}\text { - expanding the scope } \\
\text { of unmanned aviation and } \\
\text { near-earth space systems; } \\
- \text { integrated solutions } \\
\text { and services based on } \\
\text { them; } \\
\text { - the emergence of a } \\
\text { new global network } \\
\text { market for services } \\
\text { (information, logistics, } \\
\text { etc.) provided by } \\
\text { unmanned vehicles that are } \\
\text { constantly in the air and in } \\
\text { low space orbits }\end{array}$ & 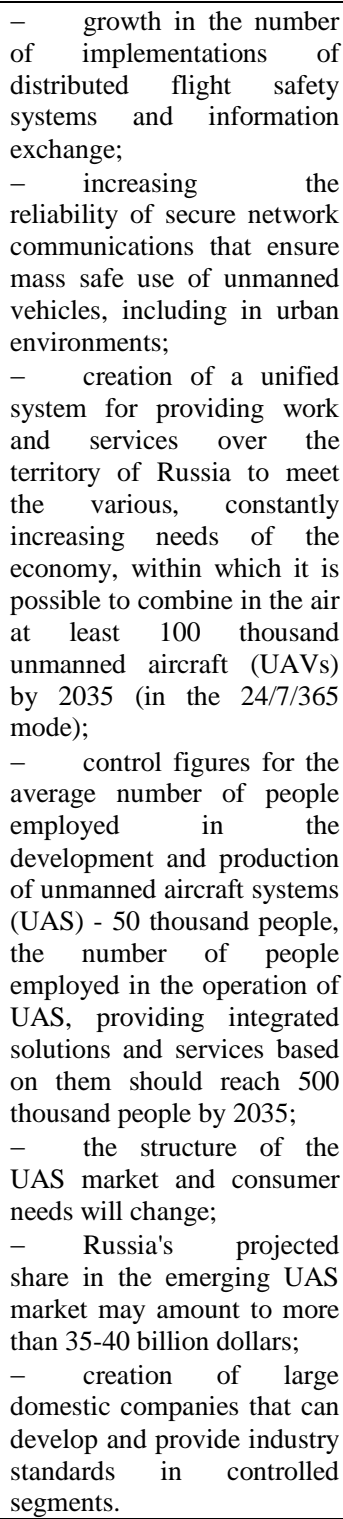 \\
\hline MariNet & $\begin{array}{lr}- & \text { maritime industry; } \\
- & \text { digital navigation (e- } \\
\text { Navigation), } & \\
-\quad \text { ocean } & \text { resource } \\
\text { development } & \text { technologies } \\
\text { and } & \text { innovative } \\
\text { shipbuilding } & \end{array}$ & $\begin{array}{l}\text { - ensuring Russia's } \\
\text { leading role in the global } \\
\text { process of creating the } \\
\text { information environment and } \\
\text { digital navigation standards; } \\
- \text { increasing the } \\
\text { attractiveness of Russian } \\
\text { ports and sea transport } \\
\text { corridors (including along } \\
\text { the Northern sea route); } \\
-\quad \text { increasing the level of } \\
\text { control over marine areas; } \\
-\quad \text { expansion of the } \\
\text { availability zone of the } \\
\text { Russian natural resources } \\
\text { base; creation of strategic }\end{array}$ \\
\hline
\end{tabular}

\begin{tabular}{|c|c|c|}
\hline & & $\begin{array}{l}\text { reserves; } \\
-\quad \text { expanding prospects } \\
\text { for the development of } \\
\text { mineral and energy resources } \\
\text { of The world's oceans; } \\
-\quad \text { increasing the } \\
\text { efficiency of the Arctic and } \\
\text { Far East resource } \\
\text { development process; } \\
-\quad \text { strengthening the } \\
\text { competitiveness of Russian } \\
\text { shipping companies, as well } \\
\text { as companies operating in } \\
\text { the field of production and } \\
\text { production of aquaculture; } \\
-\quad \text { increasing the } \\
\text { competitiveness of domestic } \\
\text { shipbuilding, reducing its } \\
\text { dependence on foreign } \\
\text { technologies, with a greater } \\
\text { degree in the field of military } \\
\text { shipbuilding. }\end{array}$ \\
\hline AutoNet & $\begin{array}{l}\text { - automation of the } \\
\text { transport system; } \\
-\quad \text { development of } \\
\text { systems for auto-pilot } \\
\text { vehicles. }\end{array}$ & $\begin{array}{l}\text { - increase in the share } \\
\text { of freight transport by road } \\
\text { from } 60 \% \text { to } 72 \% \text { by } 2025 \% \text {; } \\
-\quad \text { full autonomy of } \\
\text { road transport by } 2035 ; \\
-\quad \text { implementation of } \\
\text { the driver's assistant system } \\
\text { (ADAS) by } 2018 \text {; } \\
-\quad \text { achieving partial, } \\
\text { high, and full autonomy by } \\
2020 \text {, 2025, and 2035, } \\
\text { respectively. }\end{array}$ \\
\hline HealthNet & $\begin{array}{l}\text { an open ecosystem that } \\
\text { supports and develops } \\
\text { companies that create, } \\
\text { manufacture and provide } \\
\text { biotechnological and } \\
\text { medical products and } \\
\text { services that lead to } \\
\text { significant improvements } \\
\text { in human health and } \\
\text { quality of life }\end{array}$ & $\begin{array}{l}\text { - prospects for the } \\
\text { development of the global } \\
\text { market volume of HealthNet } \\
\text { in the global health market } \\
\text { should reach } 2 \text { trillion dollars } \\
\text { by } 2020 \text { and more than } 9 \\
\text { trillion dollars by } 2035 \text {; } \\
- \text { the Russian market } \\
\text { share of HealthNet is } \\
\text { projected to be at least } 3 \% \text { of } \\
\text { the global volume by } 2035 \text {. }\end{array}$ \\
\hline NeuroNet & $\begin{array}{l}-\quad \text { Neurotechnology; } \\
-\quad \text { integration of the } \\
\text { human brain and } \\
\text { computers }\end{array}$ & $\begin{array}{l}\text { - development of the } \\
\text { current Internet (Web 4.0), in } \\
\text { which the interaction of } \\
\text { participants (human-human, } \\
\text { human-machine) will be } \\
\text { carried out using new } \\
\text { neurocomputer interfaces; } \\
-\quad \text { development based on } \\
\text { hybrid digital-analog } \\
\text { architectures of } \\
\text { neuromorphic computers } \\
\text { (similar to the brain); } \\
-\quad \text { emergence } \\
\text { development of social neural } \\
\text { networks and full-fledged } \\
\text { hybrid human-machine } \\
\text { intelligence; introduction } \\
\text { int of } \\
\text { neurotechnologies in the } \\
\text { field of education, which can } \\
\text { dramatically increase the } \\
\text { volume and pace of learning } \\
\text { new knowledge; } \\
\text { - development } \\
\text { memory modulation and } \\
\text { neurofitness technology }\end{array}$ \\
\hline
\end{tabular}




\begin{tabular}{|c|c|c|}
\hline & & $\begin{array}{l}\text { required for multiple } \\
\text { cognitive enhancement; } \\
- \text { development of } \\
\text { technologies that are } \\
\text { available to the mass } \\
\text { consumer, allowing the use } \\
\text { of artificial limbs and } \\
\text { additional senses; } \\
- \text { neuro-management of } \\
\text { household space; } \\
-\quad \text { the emergence of } \\
\text { effective biomarkers and } \\
\text { drugs with targeted } \\
\text { properties that provide } \\
\text { treatment for various age- } \\
\text { related dementias, including } \\
\text { Alzheimer's disease and } \\
\text { Parkinson's disease. }\end{array}$ \\
\hline EnergyNet & $\begin{array}{l}\text { market of equipment, } \\
\text { software, engineering and } \\
\text { service services intended } \\
\text { for complex systems of } \\
\text { various scales and services } \\
\text { of intellectual energy }\end{array}$ & 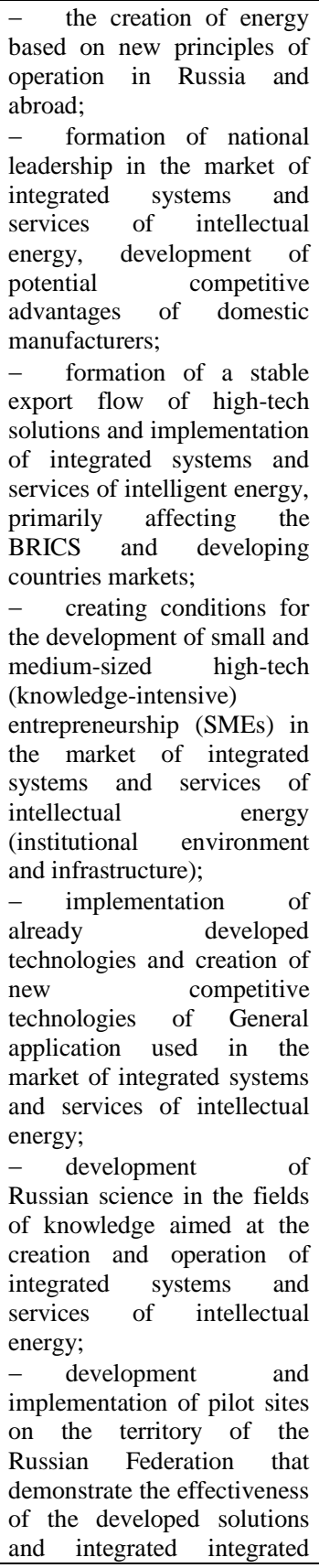 \\
\hline
\end{tabular}

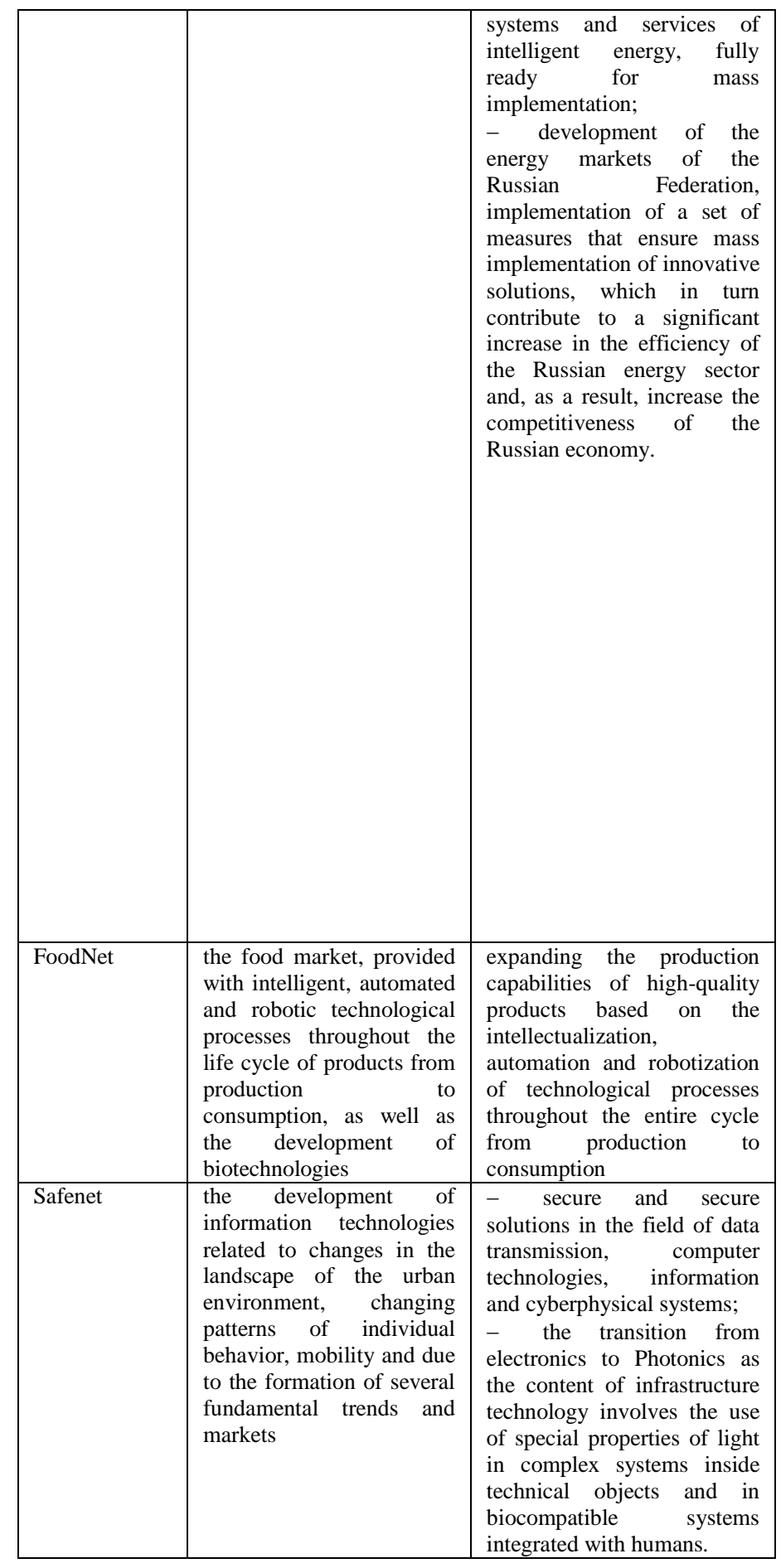

Among the significant number of problems in the development and implementation of the digital economy in Russia, we highlight the main:

- Low level of development of the legal and regulatory framework;

- Low level of institutional infrastructure; 
- A significant gap in the level of technology development in various sectors of economy (digital inequality);

- Insufficient information security of the state / business / citizens;

- Consequences of structural changes in the internal and external labor markets;

- Disadvantages of the system of training qualified personnel (higher school, secondary school).

\section{RESULTS}

The problems of formation and development of the digital economy can be demonstrated only in one of the examples in terms of structural changes in the labor market. The research conducted by the experts showed that the most popular profession in Russia in 2019 is a driver (7 \% of the employed population), an indicator that is typical for all regions. At the same time, the introduction of the concept of industry 4.0 in many countries, including Russia, causes the presence of "dying" professions and, consequently, the release of personnel (figure 1) [7-10].



Fig. 1. Industry 4.0 Concepts and related digital technologies.

According to German Gref, the head of Sberbank, a shortage of personnel able to work with artificial intelligence is among the obstacles to the transition to the digital economy.

According to him, lawyers without knowledge in the field of artificial intelligence are no longer needed by modern companies [11-12].

\section{CONCLUSION}

The transition to a digital economy has not only positive aspects because rapid productivity growth can be accompanied by the disappearance of many professions. This was stated by Russian Prime Minister Dmitry Medvedev at the Moscow financial forum: "Technological transformation based on the digital economy can lead not only to explosive growth in labor productivity, but also, on the other hand, it may kill entire professions, and increase the risks of income polarization [13]. It is critical for us to be ready for new challenges in such key state institutions as the health care system, education, social assistance, employment support and modernization of the state apparatus."

Both foreign and Russian experience suggests that only $20 \%$ of the working-age population is in demand for the new economy (digital economy, Industry 4.0) [14]. For Russia, the risks from the digital economy are higher than for other countries. The reason is the demography and aging of the population. Digitalization will be a big problem, but in General it is just a restructuring of economy - some professions that existed five or ten years ago have already disappeared without digital revolution [15].

Digital economy is becoming a prerequisite for Russian economy to become modern and competitive. The transition of Russian economy towards digitalization has both its undeniable advantages and possible risks in the long and short term. The study of possible directions of gradual development and proposed strategies will allow looking at the prospects for large-scale reforms in economy, taking into account industry characteristics. 


\section{References}

[1] Selivanov S.G., Shaykhulova A.F., Poezzhalova S.N., Yakhin A.I. Innovative design of digital production in mechanical engineering. tutorial. - Ufa: USATU, 2016 .- 260 p.

[2] Tarasenko V. Territorial Clusters: Seven Management Instruments. - M $\therefore$ Alpina Publisher, 2015 .- 201 p.

[3] Chesbro G. Open Innovation. Creation of profitable technologies. / Per. from English - M.: Generation, 2007 .- 336 p.

[4] Solomentsev Yu.M., Mitrofanov V.G., Pavlov V.V., Rybakov A.V. Information and computing systems in mechanical engineering: CALStechnology. / Tutorial. - M .: Nauka, 2003 .- 292 p.

[5] Baranova I.V. Enterprise management based on integrated means of supporting distributed databases // Bulletin of the South Russian State Technical University (Novocherkassk Polytechnic Institute). - 2013. No. 1. - p. 110-118.

[6] Zhuravlev Y.V., Kuksova I.V., Gubertov E.A., Churikov L.I. Evaluation of innovative development of the Russian Federation based on the 2020 vision and strategy indicators. Proceedings of the Voronezh State University of Engineering Technologies. 2019;81(2):377-382. (In Russ.) https://doi.org/10.20914/2310-1202-2019-2-377-382

[7] "Industry 4.0": the creation of a digital enterprise. Global review of the implementation of the Industry 4.0 concept for 2016. URL: http: //www.pwc.ru/ru/technology/assets/global_industry-2016_rus.pdf (accessed: 01/21/2018).

[8] Salikov Y.A., Logunova I.V., Kablashova I.V. Trends in human resource management in the digital economy. Proceedings of the Voronezh State University of Engineering Technologies. 2019;81(2):393-399. (In Russ.) https://doi.org/10.20914/2310-12022019-2-393-399

[9] Chekudaev K.V., Suyazova G.A., Motina E.A., Matvienko N.A. Application financial analysis methods for the designing of innovative food enterprises, aimed at import substitution. Proceedings of the Voronezh State University of Engineering Technologies.
2019;81(1):397-401. (In Russ.) https://doi.org/10.20914/2310-12022019-1-397-401

[10] Afanasiev M.Y., Lysenkova M.A. Approach to the analysis and comparison of national innovation systems on the example of Russia and other countries. Proceedings of the Voronezh State University of Engineering Technologies. 2019;81(1):434-442. (In Russ.) https://doi.org/10.20914/2310-1202-2019-1-434-442

[11] Narolina J.V., Sabetova T.V., Shabutskaya N.V., Gryshchenko N.V. The influence of innovative development on economic security of the region. Proceedings of the Voronezh State University of Engineering Technologies. 2019;81(1):457-463. (In Russ.) https://doi.org/10.20914/2310-1202-2019-1-457-463

[12] Serebryakova N.A., Avdeev I.V. The content of structural transformations of the region's economy, adequate to the requirements of digitalization. Proceedings of the Voronezh State University of Engineering Technologies. 2018;80(4):408-412. (In Russ.) https://doi.org/10.20914/2310-1202-2018-4-408-412

[13] Asmolova M.S., Dedov S.V. The algorithm to ensure and implement the strategy of the effective management of innovation processes. Proceedings of the Voronezh State University of Engineering Technologies. 2018;80(4):436-440. (In Russ.) https://doi.org/10.20914/2310-1202-2018-4-436-440

[14] Serebryakova N.S., Petrikov A.V. The principles of design and the organization of functioning of innovative infrastructures in the conditions of the Industry 4.0. Proceedings of the Voronezh State University of Engineering Technologies. 2018;80(4):384-387. (In Russ.) https://doi.org/10.20914/2310-1202-2018-4-384-387

[15] Anisimov Y.P., Zhuravlev Y.V., Kuksova I.V., Balabanova E.I., Zhilnikov A.Y., Elagina T.V. Spatial analysis of the development of innovative potential of enterprises. Proceedings of the Voronezh State University of Engineering Technologies. 2019;81(1):391-396. (In Russ.) https://doi.org/10.20914/2310-1202-2019-1-391-396 